\title{
Process development and optimization of fed-batch production processes for therapeutic proteins by CHO cells
}

\author{
Marie-Françoise Clincke* , Mareike Harmsen, Laetitia Malphettes \\ From 23rd European Society for Animal Cell Technology (ESACT) Meeting: Better Cells for Better Health \\ Lille, France. 23-26 June 2013
}

\begin{abstract}
Background
In the biopharmaceutical industry, process development and optimization is key to produce high quality recombinant proteins at high yields. As technologies mature, pressure on cost and timelines becomes greater for delivering scalable and robust processes. Overall, process development should be viewed as a continuum from the early stages up to process validation. Here we outline a lean approach on upstream development during the initial phases to optimize yields while maintaining the desired product quality profiles. Early-stage process development was designed to lead to the establishment of a baseline process and to systematically include experiments with input parameters that have a high impact on performance and quality. At this stage, potential for pre-harvest titer and yield increases as well as product quality challenges were identified. Feed adjustments and systematic experiments with top, high, and medium impact parameters have then been performed to develop a robust and scalable process. This approach was applied to two early stage upstream processes.
\end{abstract}

\section{Materials and methods}

$2 \mathrm{~L}$ and $80 \mathrm{~L}$ stirred tank bioreactors were run for 14 days in a fed-batch mode in a chemically defined medium. Feed was added daily from day 3 onwards. If required, antifoam $\mathrm{C}$ was added to the bioreactor by manual injections. $\mathrm{DO}, \mathrm{pH}$, and temperature were controlled at setpoint. DO was controlled using a multi-stage aeration cascade via a ring sparger. Viable cell concentration, cell viability, and average cell diameter were measured using a ViCell cell counter. The glucose, lactate, glutamine and

\footnotetext{
* Correspondence: Marie-Francoise.Clincke@ucb.com

Cell Culture Process Sciences Group, BioTech Sciences, UCB Pharma S.A.,
} Braine L'Alleud, Belgium

\section{Results}

A lean and Quality by Design (QbD) approach on process development during the initial phases to optimize yields while maintaining the desired product quality proes was adopted. In this approach, a workpackage the expected high impact parameters (feeding tegy, seeding density, $\mathrm{pH}$, temperature and the interaction studies) was defined. This workpackage was applied to the process development of a cell line 1 producing a monoclonal antibody and led to a $36 \%$ increase in the monoclonal antibody titer compared to control condition (data not shown). Then, the operational process parameters and feeding strategy developed for cell line 1 (process 1 ) were applied to a cell line 2 producing a monoclonal antibody fragment. The application of the process 1 strategy to a cell line 2 was not the best for cell line 2 and led to high $\mathrm{pCO}_{2}$ level, high ammonia concentration, high osmolalities and low monoclonal antibody fragment titers (Figure 1). A feeding strategy was optimized for cell line 2 and $\mathrm{pH}$ set-point and deadband were also adjusted in order to decrease the $\mathrm{pCO}_{2}$ level. This optimized process for cell line 2 led to higher performances $\left(\mathrm{pCO}_{2}\right.$, ammonia concentration, and osmolalities values were maintained at a low level) with a $43 \%$ increase in the monoclonal antibody fragment titer (data not shown). Then both processes were scaled up to $80 \mathrm{~L}$ stirred tank bioreactors and comparable monoclonal antibody titers were obtained at $2 \mathrm{~L}$ scale and $80 \mathrm{~L}$ scale 

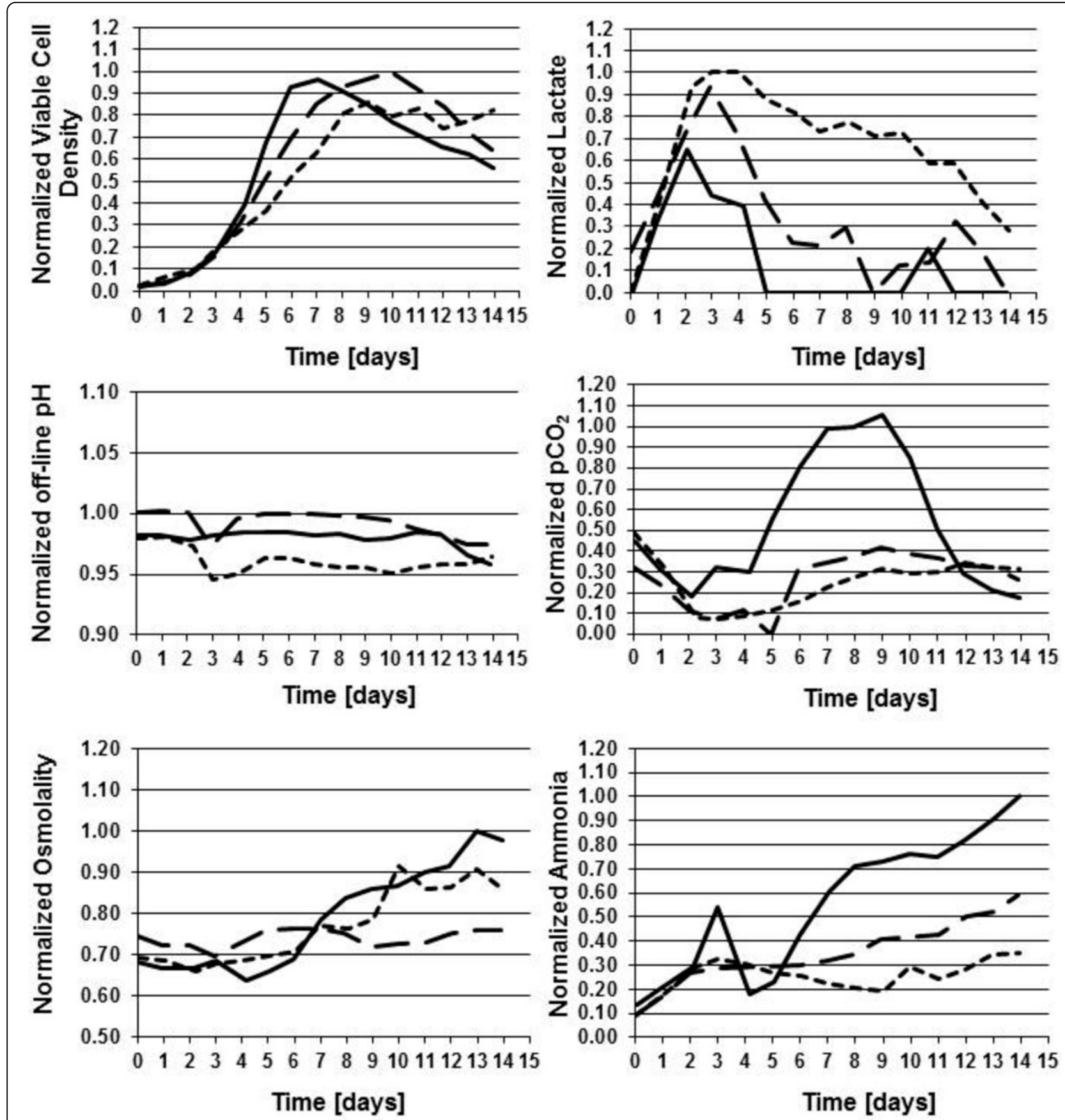

Figure 1 Viable cell concentration and off-line $\mathrm{pH}, \mathrm{pCO}_{2}$, osmolality, lactate and ammonia profiles during fed-batch culture (solid black line: cell line 2, process 1 strategy, short dash line: cell line 1, process 1, long dash line: cell line 2, process 2)

Table 1 Comparison of MAb titers (normalized) obtained for both cell lines at $2 \mathrm{~L}$ scale and $80 \mathrm{~L}$ scale

\begin{tabular}{lll}
\hline & Cell line 1, Process $\mathbf{1}$ & Cell line 2, Process $\mathbf{2}$ \\
\hline 2L scale & 1.00 & 1.00 \\
80L scale & 0.99 & 1.09 \\
\hline
\end{tabular}

(Table 1). For the cell line 1, Product Quality Attributes such as Acidic Peak Group, aggregate and Mannose 5 were assessed and were maintained within the expected ranges with scale-up (data not shown).

\section{Conclusions}

A similar process development approach was applied to both projects where identical high impact parameters 
were identified. Although process optimized for cell line 1 was not the best for cell line 2 , we were able to use it as a starting point and were able to optimize within the tight timelines. For both projects, high titers were achieved following our lean approach on process development. The final process 1 optimized for a cell line 1 led to a $36 \%$ increase in monoclonal antibody titer. The final process 2 optimized for a cell line 2 led to a $43 \%$ increase in monoclonal antibody fragment titer. Comparable titers and product quality attributes were observed at $2 \mathrm{~L}$ scale and $80 \mathrm{~L}$ scale. Hence the adopted feeding strategy proved to be robust and scalable.

Published: 4 December 2013

Cite this article as: Clincke et al:. Process development and optimization

of fed-batch production processes for therapeutic proteins by $\mathrm{CHO}$ cells. BMC Proceedings 2013 7(Suppl 6):P79.

Submit your next manuscript to BioMed Central and take full advantage of:

- Convenient online submission

- Thorough peer review

- No space constraints or color figure charges

- Immediate publication on acceptance

- Inclusion in PubMed, CAS, Scopus and Google Scholar

- Research which is freely available for redistribution

Submit your manuscript at www.biomedcentral.com/submit 